\title{
Multiple resistance to atrazine and imazethapyr in hairy beggarticks (Bidens pilosa)
}

\author{
Resistência múltipla a atrazina e imazethapyr em picão-preto (Bidens pilosa)
}

\author{
Hudson Kagueyama Takano ${ }^{1 *}$, Rubem Silvério de Oliveira Junior ${ }^{1}$, Jamil Constantin', \\ Guilherme Braga Pereira Braz ${ }^{1}$, Luiz Henrique Morais Franchini ${ }^{1}$, Nilda Roma Burgos ${ }^{2}$
}

\author{
${ }^{1}$ Universidade Estadual de Maringá/UEM, Maringá, PR, Brasil \\ 2University of Arkansas - Fayetteville, Arkansas, USA \\ ${ }^{*}$ Corresponding author: hudsontakano@gmail.com \\ Received in May 30, 2016 and approved in July 29, 2016
}

\begin{abstract}
Resistance to herbicides is a serious threat to crop production worldwide, especially in agronomic crops and cereals. This research evaluated the possible occurrence of Bidens pilosa resistant to imazethapyr and atrazine in Brazil. The resistant biotype was collected from an area with a history of repeated application of photosystem II (PSII) and ALS inhibitor herbicides. The susceptible biotype was collected from an area with no history of herbicide application. Resistance verification experiments were carried out in the greenhouse. The treatments were arranged in a $3 \times 8$ factorial scheme, where the first factor was populations [susceptible (S), parent resistant (PR), and resistant F1 (RF1)]; and the second factor was herbicide dose $\left(0,375,750,1500,3000,6000,12000\right.$ and $24000 \mathrm{~g}$ ha $^{-1}$ for atrazine; or 0, 12.5, 25, 50, 100, 200, 400 and $800 \mathrm{~g} \mathrm{ha}^{-1}$ for imazethapyr). The resistance factor to atrazine was 2.83 for PR and 5.55 for RF1. This population was more resistant to imazethapyr (>21-fold) than it was to atrazine. The recommended maximum dose of the herbicides did not control this B. pilosa population adequately. The data support the claim that B. pilosa population from this field in Quarto Centenário, Parana is resistant to two herbicide modes of action - PSII inhibitor (i.e. atrazine) and ALS inhibitor (i.e. imazethapyr). This is the first report of such case for this species, globally. Cross-resistance to other ALS inhibitors and other PS II inhibitors as well as the respective mechanisms of resistance to each herbicide are being investigated.
\end{abstract}

Index terms: Photosystem II; resistance level; herbicide resistance.

\begin{abstract}
RESUMO
A resistência de plantas daninhas à herbicidas constitui uma das principais ameaças para a agricultura no mundo, especialmente para a produção de grãos. O presente trabalho objetivou verificar a possível existência de Bidens pilosa resistente a imazethapyr e atrazina. Dois experimentos foram realizados em casa-de-vegetação, sendo um para cada herbicida. O biótipo resistente foi proveniente de área com histórico de aplicações de herbicidas inibidores do fotossistema II e da ALS, enquanto que o biótipo suscetível foi coletado em área sem histórico de aplicação de herbicidas. Os tratamentos foram dispostos em esquema fatorial $3 \times 10$, em que o primeiro fator foi composto por diferentes populações [suscetível (S), resistente parental (RP) e resistente F1 (RF1)], e o segundo fator constituiu de doses

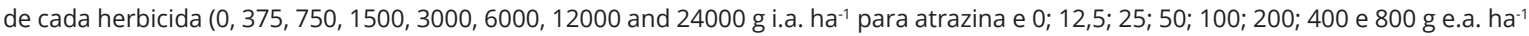
para imazethapyr). O fator de resistência variou entre 2,83 e 5,55 para atrazina e >21 para imazethapyr. Além disso, a dose máxima de registro dos herbicidas não controlou as plantas do biótipo resistente. Os resultados revelaram que a população de B. pilosa proveniente de Quarto Centenário, Paraná, apresenta resistência múltipla a dois mecanismos de ação: inibidores da ALS (atrazine) e do fotossistema II (imazethapyr). Este é o primeiro relato deste tipo de resistência nesta espécie no mundo. A resistência cruzada a outros herbicidas destes dois mecanismos, bem como o mecanismo de resistência estão sendo investigados.
\end{abstract}

Termos para indexação: Fotossistema Il; fator de resistência; resistência a herbicidas.

\section{INTRODUCTION}

Resistance to herbicides has become an important problem in crop production worldwide over the last two decades. In Brazil, 36 unique cases have been reported so far on weed species with resistance to at least one mechanism of action; $61.8 \%$ of these cases are related to biotypes with resistance to acetolactate synthase (ALS) inhibitors, and $11.8 \%$ to inhibitors of photosystem II (PSII) (Heap, 2016).
Species with confirmed resistance to herbicides, two of the most widespread in Brazil are Bidens pilosa (BIDPI) and Bidens subalternans (BIDSU). Both species, locally known as "picão-preto", are very similar morphologically and are distributed widely over agricultural areas and along roadsides, in tropical and subtropical regions of the country (Grombone-Guaratini; Solferini; Semir, 2004). The main morphological differences between BIDPI and BIDSU are 
in the cypselae, the typical Asteraceae achene-like fruit: most cypselae in BIDPI have three aristae, as compared to four in BIDSU. Also, the angle between the aristae and the cypselae in BIDPI is about $135^{\circ}$, while in BIDSU is $180^{\circ}$. The corolla of the marginal flowers is white in BIDPI and yellow or orange in BIDSU. BIDPI also has broader leaf segments, while BIDSU has narrower leaf segments (Grombone-Guaratini; Solferini; Semir, 2004; Lopez-Ovejero et al., 2006).

Resistance to ALS inhibitors in BIDPI was first reported in soybean fields from Mato Grosso do Sul in 1993. Although this biotype was selected under a 6-year imazaquin/chlorimuron rotation, it was also cross-resistant to other ALS inhibitors in the imidazolinone (imazethapyr), sulfonylurea (nicosulfuron), and pyrimidinylthiobenzoate (pyrithiobac-sodium) chemical groups. The resistance in BIDPI was due to target site mutation in the $A L S$ gene (Heap, 2016). Resistance to ALS inhibitors in BIDSU was subsequently confirmed in 1996 for the herbicides chlorimuron, imazethapyr and nicosulfuron also in soybean fields from Mato Grosso do Sul. Afterwards, in 1996, multiple resistance to ALS (foramsulfuron and iodosulfuron methyl sodium) and PSII inhibitors (atrazine) was reported for BIDSU biotypes in corn (Heap, 2016). Resistance to herbicides that inhibit the ALS enzyme has been attributed to amino acid alteration(s) in the ALS protein. Lamego et al. (2009) demonstrated that resistance to ALS inhibitors in BIDSU was correlated to one of the following amino acid substitutions in the resistant biotype: $\operatorname{Trp}_{574}$ Leu, Phe ${ }_{116}$ Leu or Phe ${ }_{149}$ Ser.

Many grain-producing farmers of West-Central and Southern regions of Brazil practice soybean-corn double cropping. Before glyphosate-resistant (GR) soybean was introduced in Brazil in 2006, the recurrent use of ALS inhibitors in soybean and of PSII inhibitors in corn was the primary driver for resistance selection.

Once selected, resistant biotypes of BIDPI tend to spread quickly, due to its rapid growth, short life cycle, and to the special structures on the aristae that facilitate adhesion to surfaces, increasing its capacity to colonize new areas (Baio; Pires; Tomquelsk, 2013). Despite its high tendency to spread, the predicted increase in importance of the resistant biotypes of BIDPI did not occur, probably due to the gradual substitution of conventional soybeans with GR varieties and to the high sensitivity of Bidens spp. to glyphosate (Braz et al., 2011).

Ten years after the introduction of GR soybean in Brazil, at least seven species have evolved resistance to glyphosate and "traditional" herbicides such as imidazolinones, sulfonylureas, triazolopyrimidines and triazines are again widely used both for in-crop and offseason weed management (Oliveira Neto et al., 2010). All the eight cases of multiple resistance reported in Brazil so far (Heap, 2016) include resistance to ALS inhibitors, PSII inhibitors or both.

Economic losses due to the reduced effectiveness of herbicides on BIDPI are evident, both in terms of reduced yield volumes and reduction of grain quality (Freitas et al., 2006; Faria; Barros; Tuffi Santos, 2014). Within this context, this research aimed to confirm the resistance of Bidens pilosa from Parana to imazethapyr and atrazine.

\section{MATERIAL AND METHODS}

Seeds of the putative resistant (R) population were obtained from a farm located at Quarto Centenário,

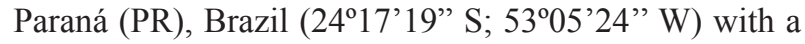
history of at least six years of applications of PSII and ALS inhibitor herbicides in a continuous soybean-corn double cropping rotation. Seeds of the susceptible (S) population were collected from an isolated urban area in Paranavaí, PR, (2305'46" S; 53 $27^{\circ} 14^{\prime \prime}$ W) with no history of herbicide application. Plants from the field-collected $\mathrm{R}$ population were also grown separately in a greenhouse to produce seeds. Henceforth, the field-collected seeds will be referred to as the 'parent resistant' (PR) population and the progeny of these resistant, field-collected plants will be referred to as the 'resistant F1 (RF1) population. Due to the morphological similarities of BIDPI to other species such as BIDSU, a voucher specimen was collected and deposited at the Herbarium of the State University of Maringá, where it was positively identified as Bidens pilosa L. under the record HUEM 29220.

Several commercial formulations of atrazine and imazethapyr are recommended for the control of BIDPI in Brazil. Among the atrazine formulations, more than $80 \%$ have a label dose of 1600 to $3000 \mathrm{~g}$ a.i ha ${ }^{-1}$ for postemergence control of BIDPI. For imazethapyr, all labels in Brazil recommend a dose range of 85.6 to $100 \mathrm{~g}$ a.e $\mathrm{ha}^{-1}$. For the purposes of this study, the highest recommended dose for each herbicide (3000 $\mathrm{g} \mathrm{ha}^{-1}$ for atrazine and 100 $\mathrm{g} \mathrm{ha}^{-1}$ for imazethapyr) was used, and the range for the dose-response assays was established based on these doses.

Each experiment was set in a $3 \times 8$ factorial scheme in randomized complete blocks with four replications. The first factor was population (S, PR, and RF1) and the second factor was herbicide dose $[0,375,750,1500,3000,6000$, 12000 and $24000 \mathrm{~g}$.i ha ${ }^{-1}$ for atrazine (Primoleo ${ }^{\circledR}$ SC, 400 $\mathrm{g}$ a.i $\mathrm{L}^{-1}$, Syngenta Brazil); and 0, 12.5, 25, 50, 100, 200,

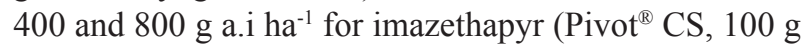
a.i L ${ }^{-1}$, BASF Brazil)]. 
The experimental units were composed of $1.0 \mathrm{dm}^{3}$ pots, filled with a commercial substrate (Plantmax HA ${ }^{\circledR}$ ). Thirty seeds were planted per pot and seedlings were thinned to three per pot. The herbicides were applied when plants had four to six leaves. All applications were made with a $\mathrm{CO}_{2}$ backpack sprayer and a $1.5-\mathrm{m}$ boom fitted with three AI 110.02 nozzles $(0.5 \mathrm{~m}$ between tips) that were calibrated to deliver $200 \mathrm{~L} \mathrm{ha}^{-1}$ at $245 \mathrm{kPa}$. During herbicide application, the relative humidity was $65 \%$, air temperature was $25^{\circ} \mathrm{C}$ and wind velocity was $\leq 0.33 \mathrm{~m} \mathrm{~s}^{-1}$.

Weed control was evaluated visually at 28 days after application (DAA) using a scale of 0 to $100 \%$, where $0 \%$ represents no control and $100 \%$ represents death. Also at $28 \mathrm{DAA}$, the remaining shoots were harvested, placed in paper bags, dried $\left(65^{\circ} \mathrm{C}\right.$ for $\left.72 \mathrm{~h}\right)$ and weighed (g per pot). Data were subjected to analysis of variance and regression, and adjusted for the nonlinear logistic regression model proposed by Streibig (1988) (Equation 1):

$$
y=\frac{a}{\left[1+\left(\frac{x}{b}\right)^{c}\right]}
$$

Where: $y$ is the percentage control; $x$ is the dose of herbicide ( $\left.\mathrm{g} \mathrm{ha}^{-1}\right)$; and $a, b$ and $c$ are estimated parameters of the equation: $a$ is the amplitude between the maximum and the minimum point of the variable; $b$ is the dose which provides $50 \%$ response; and $c$ is the slope of the curve around $b$.

One of the integral terms of the equation for the logistic model $(b)$ is an estimate of the value of $\mathrm{C}_{50}$ or $\mathrm{GR}_{50} \cdot \mathrm{C}_{50}$ and $\mathrm{GR}_{50}$ are the herbicide doses which reduced, respectively, weed control or shoot dry weight by $50 \%$. Although one of the parameters of the logistic model (b) is a $\mathrm{C}_{50}$ or $\mathrm{GR}_{50}$ estimate, a mathematical solution of these values was estimated using the inverse equation, as proposed by Carvalho et al. (2005) (Equation 2):

$$
x=b\left(\left|\frac{a}{y}-1\right|\right)^{\frac{1}{c}}
$$

Based on $\mathrm{C}_{50}$ and $\mathrm{GR}_{50}$, the resistance factor (RF) was calculated as $\mathrm{C}_{50}$ or $\mathrm{GR}_{50}$ of the resistant population $/ \mathrm{C}_{50}$ or $\mathrm{GR}_{50}$ of the susceptible standard). This value expresses the number of times that the dose necessary to control $50 \%$ of the resistant population is greater than the dose which controls $50 \%$ of the susceptible (Burgos et al., 2013). In addition to $C_{50}$ and $\mathrm{GR}_{50}$, the values for $\mathrm{C}_{80}$ and $\mathrm{GR}_{80}$ were also estimated with the inverse equation because these values have practical implication in gauging potential economic impact of the resistant population under field conditions (SBCPD, 1995).

For the purpose of this work, the populations were considered resistant when $\mathrm{RF} \geq 2.0$ and simultaneously satisfied two additional conditions: $\mathrm{C}_{80}$ and $\mathrm{GR}_{80}$ values $>$ highest recommended dose to control this species (Francischini et al., 2014; Santos et al., 2014).

\section{RESULTS AND DISCUSSION}

\section{Resistance to atrazine}

The model proposed by Streibig (1988) adequately described \% control and shoot dry weight response of BIDPI to atrazine. Based on the fitted models, doses of atrazine required for $50 \%$ and $80 \%$ control, as well as for the shoot dry weight of each population were estimated (Table 1).

The recommended dose of atrazine postemergence for BIDPI is within the range of 1 to $1.5 \mathrm{~kg} \mathrm{ha}^{-1}$ (Rodrigues; Almeida, 2011). With this dose, the susceptible population should be adequately controlled by atrazine, which is reflected by the $\mathrm{C}_{80}$ and $\mathrm{GR}_{80}$ values. For instance, by using the lowest recommended dose $\left(1 \mathrm{~kg} \mathrm{ha}^{-1}\right)$, the predicted response of the S population would be $92.9 \%$ control or $99.7 \%$, dry matter reduction.

Based on $\mathrm{C}_{50}$ values, it would take 4.6 times as much atrazine to control the field-collected (PR) than the $\mathrm{S}$ population and about 7 times more atrazine to achieve $80 \%$ control of PR than it would for the $\mathrm{S}$ population. The offsprings of plants that survived atrazine application in the field (RF1) required similar amount of atrazine to attain $50 \%$ or $80 \%$ control as PR. Similar response pattern was also observed with biomass reduction between PR and RF1 relative to the $\mathrm{S}$ biotype. All together, this showed that the acquired ability of PR to tolerate atrazine is heritable and that PR is resistant to atrazine.

The fact that the progenies had similar resistance level as the parents is expected in autogamous plants such as those of the genus Bidens. Although autogamous, BIDPI and BIDSU are genetically compatible and can cross-pollinate at low levels (up to 9\%), depending on the presence of pollinators (Grombone-Guaratini; Solferini; Semir, 2004; Vidal et al., 2006; Huang; Kao, 2014). Conversely, the findings in our work raise the hypothesis that resistance in BIDPI could also spread to BIDSU. 
The dose of atrazine required to control or reduce shoot dry weight by $80 \%$ was 4,194 and 3,901 $\mathrm{g} \mathrm{ha}^{-1}$ in PR and RF1, respectively, indicating that the maximum dose recommended in commercial formulations of atrazine $\left(1.5 \mathrm{~kg} \mathrm{ha}^{-1}\right)$ is no longer effective (41.6 to $56.6 \%$ ) on this field population and its progenies. Conversely, the doses to control or reduce dry weight at least by $80 \%$ of the S population were 547 and $479 \mathrm{~g} \mathrm{ha}^{-1}$, respectively, indicating the expected level of performance of the commercial label dose (Figures 1 and 2). To the best of our knowledge, this is the first report of resistance in BIDPI to a photosystem II inhibitor anywhere in the world.

Atrazine-susceptible BIDPI have been controlled $(100 \%)$ with doses ranging from 1500 to $1600 \mathrm{~g} \mathrm{ha}^{-1}$ applied both pre and postemergence, including those reported as ALS-resistant (Dan et al., 2010; Guerra et al., 2011).

\section{Resistance to Imazethapyr}

The response of PR and RF1 to imazethapyr in terms of $\%$ control did not fit the Streibig model, although the model describes the response of S population well (Table 2). Even the highest dose used $\left(800 \mathrm{~g} \mathrm{ha}^{-1}\right)$, which is $\approx 8 \mathrm{x}$ the recommended dose, was less than $50 \%$ effective on the putative resistant population and its progeny. The model was adjusted for the dry matter data and all parameters were significantly; however, the estimated $\mathrm{GR}_{50}$ and $\mathrm{GR}_{80}$ were outside the tested dose range $\left(>800 \mathrm{~g} \mathrm{ha}^{-1}\right)$. Given that the highest dose tested $\left(800 \mathrm{~g} \mathrm{ha}^{-1}\right)$ was not enough to provide at least $50 \%$ control, and that the $\mathrm{C}_{50}$ for the $\mathrm{S}$ population was $37 \mathrm{~g} \mathrm{ha}^{-1}$, we could say that the PR and RF1 plants had $>21$ times the capability of the susceptible plants to tolerate the commercial dose of imatzethapyr. Therefore, we concluded that PR is also highly resistant to imazethapyr besides being resistant to atrazine.

Table 1: Estimated parameters of the Streibig model and resistance factor (RF) for \% control or reduction of shoot dry matter accumulation in the susceptible (S), parent resistant (PR) and resistant F1 (RF1) populations, and estimated doses of atrazine to provide $50 \%$ or $80 \%$ of Bidens pilosa control or shoot dry matter reduction.

\begin{tabular}{ccccccc}
\hline & $\mathrm{R}^{2}$ & $a$ & $b\left(\mathrm{C}_{50}\right.$ or $\left.\mathrm{GR}_{50}\right)$ & $c$ & $\mathrm{RF}$ & $\mathrm{C}_{80}$ or $\mathrm{GR}_{80}$ \\
\hline \% Control S & 0.97 & 101.64 & $\mathrm{C}_{50}=260$ & -1.76 & - & $\mathrm{C}_{80}=547$ \\
\% Control PR & 0.94 & 108.22 & $\mathrm{C}_{50}=1,626$ & -1.10 & 5.6 & $\mathrm{C}_{80}=4,194$ \\
\% Control RF1 & 0.95 & 111.55 & $\mathrm{C}_{50}=1,450$ & -0.94 & 4.6 & $\mathrm{C}_{80}=3,901$ \\
Dry matter reduction S & 0.96 & 2.75 & $\mathrm{GR}_{50}=381$ & 6.05 & - & $\mathrm{GR}_{80}=479$ \\
Dry matter reduction PR & 0.89 & 3.03 & $\mathrm{GR}_{50}=1,084$ & 1.01 & 2.9 & $\mathrm{GR}_{80}=4,437$ \\
Dry matter reduction RF1 & 0.93 & 2.89 & $\mathrm{GR}_{50}=1,117$ & 1.13 & 2.8 & $\mathrm{GR}_{80}=3,884$ \\
\hline
\end{tabular}

$\mathrm{C}_{50}$; $\mathrm{C}_{80}$ or $\mathrm{GR}_{50} ; \mathrm{GR}_{80}$ : doses of atrazine which provides 50 or $80 \%$ of control or dry weigh reduction.

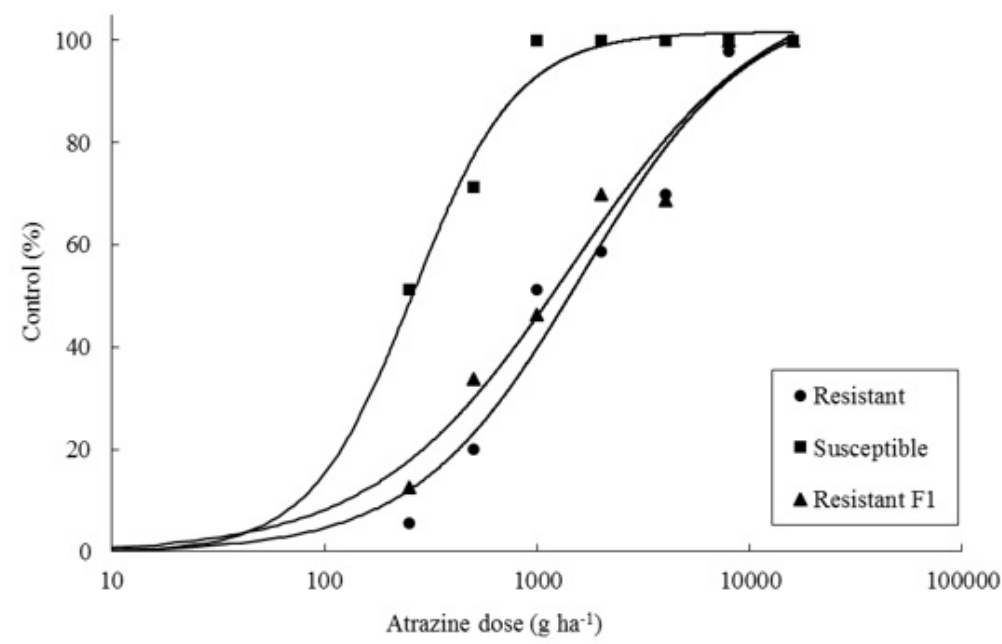

Figure 1: Response (\% control) of Bidens pilosa populations to increasing doses of atrazine 28 days after application, Maringá, PR, Brazil 2016. 


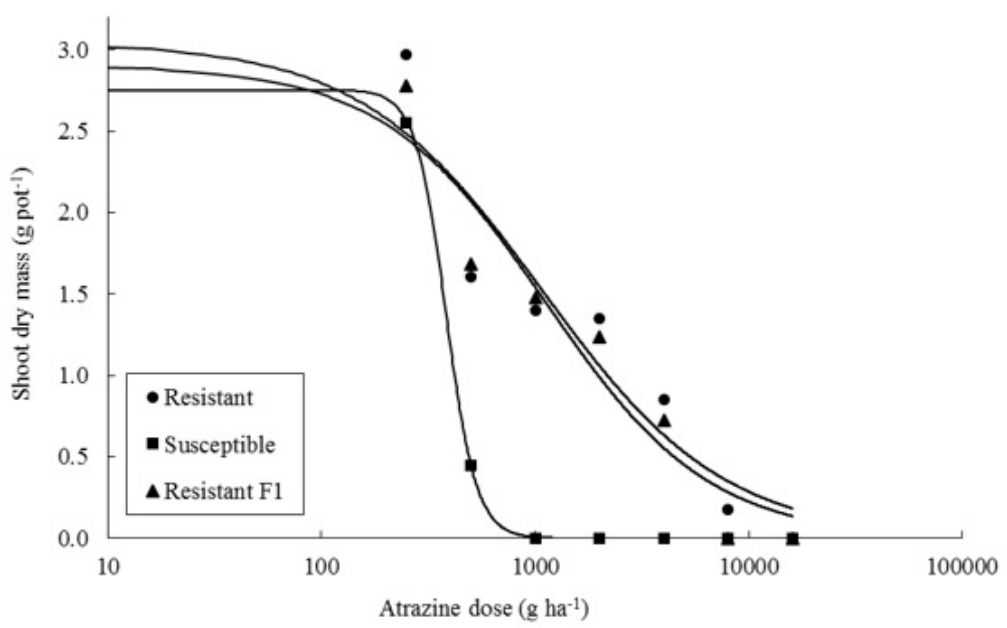

Figure 2: Response (g dry shoot biomass/pot) of Bidens pilosa populations to increasing doses of atrazine 28 days after application.

Table 2: Estimated parameters of the Streibig model and resistance factor (RF) for \% control or reduction of shoot dry matter accumulation in the susceptible (S), parent resistant (PR) and resistant F1 (RF1) populations, and estimated doses of imazethapyr to provide $50 \%$ or $80 \%$ control or shoot dry matter reduction of Bidens pilosa.

\begin{tabular}{ccccccc}
\hline & $\mathrm{R}^{2}$ & $a$ & $b\left(\mathrm{C}_{50}\right.$ or $\left.\mathrm{GR}_{50}\right)$ & $c$ & $\mathrm{RF}$ & $\mathrm{C}_{80}$ or $\mathrm{GR}_{80}$ \\
\hline \% Control S & 0.97 & 101.71 & 37 & -1.29 & $>21$ & $\mathrm{C}_{80}=102$ \\
\% Control PR & - & $\mathrm{NA}$ & $\mathrm{NA}$ & $\mathrm{NA}$ & $>21$ & $\mathrm{NA}^{1 /}$ \\
\% Control RF1 & - & $\mathrm{NA}$ & $\mathrm{NA}$ & $\mathrm{NA}$ & - & $\mathrm{NA}^{1 /}$ \\
Dry matter reduction S & 0.88 & 2.83 & 29 & 1.43 & $>27$ & $\mathrm{GR}_{80}=77$ \\
Dry matter reduction PR & 0.69 & 2.88 & $935^{2 \prime}$ & 0.63 & $>27$ & $\mathrm{GR}_{80}>800^{2 \prime} \prime$ \\
Dry matter reduction RF1 & 0.61 & 3.11 & $1944^{\prime \prime}$ & 0.37 & 2.8 & $\mathrm{GR}_{80}>800^{2 \prime}$ \\
\hline
\end{tabular}

$\mathrm{C}_{50} \mathrm{C}_{80}$ or $\mathrm{GR}_{50} ; \mathrm{GR}_{80}$ : doses of imazethapyr which provides 50 or $80 \%$ of control or dry weigh reduction; ${ }^{1 / N A}$ : not adjusted for Streibig model; 느alues outside the tested dose range.

The $\mathrm{C}_{80}$ and $\mathrm{GR}_{80}$ values for the susceptible population were similar to the recommended dose for postemergence control of BIDPI $\left(100 \mathrm{~g} \mathrm{ha}^{-1}\right)$, which means that the recommended dose had good activity on this population, although it did not provide $100 \%$ control (Figures 3 and 4). It is not unusual for weed populations to show differential tolerance to a herbicide without prior selection (Burgos et al., 2011). It is possible that this population had a higher baseline tolerance to imazethapyr than others. This same dose, however, had little to no effect on the resistant population and its progeny, resulting in minimal shoot dry matter reduction.

Our data demonstrate that the BIDPI population from Quarto Centenário has a high level of resistance to this imazethapyr $(\mathrm{RF}>21)$. Similar results were also found for other populations of BIDSU and BIDPI, where doses eight times higher than the recommended dose for imazethapyr and chlorimuron provided less than 50\% control, (Lopez-Ovejero et al., 2006). Thus, it is likely that the field population in this current study is also cross-resistant to sulfonylurea herbicides.

The mechanism that confers resistance to ALS inhibitors in resistant biotypes of BIDPI in Brazil is still unknown. Monquero, Christoffoleti and Carrer (2003) demonstrated lower sensitivity of the ALS enzyme to herbicides in resistant individuals, and a similar RF range $(>20)$ was reported for different species. Previous research with ALS-resistant BIDPI have demonstrated cross-resistance to different chemical groups including imidazolinones and sulfonylureas (chlorimuron, metsulfuron, nicosulfuron and imazethapyr) (Christoffoleti, 2002). In BIDSU, the mechanism of resistance to ALS inhibitors involves a point mutation in the $A L S$ gene $\left(\operatorname{Trp}_{574}\right.$ Leu, Phe ${ }_{116}$ Leu or Phe ${ }_{149}$ Ser), which confers high resistance level ( $\mathrm{RF}=166)$ (Lamego et al., 2009). 


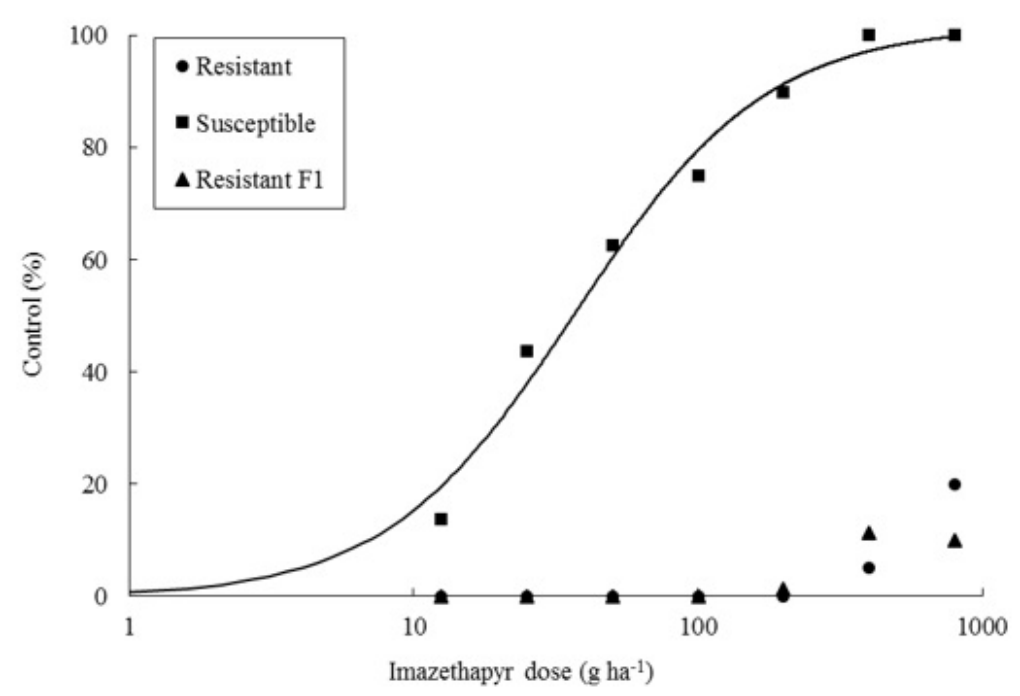

Figure 3: Response (\% control) of Bidens pilosa populations to increasing doses of imazethapyr 28 days after application.

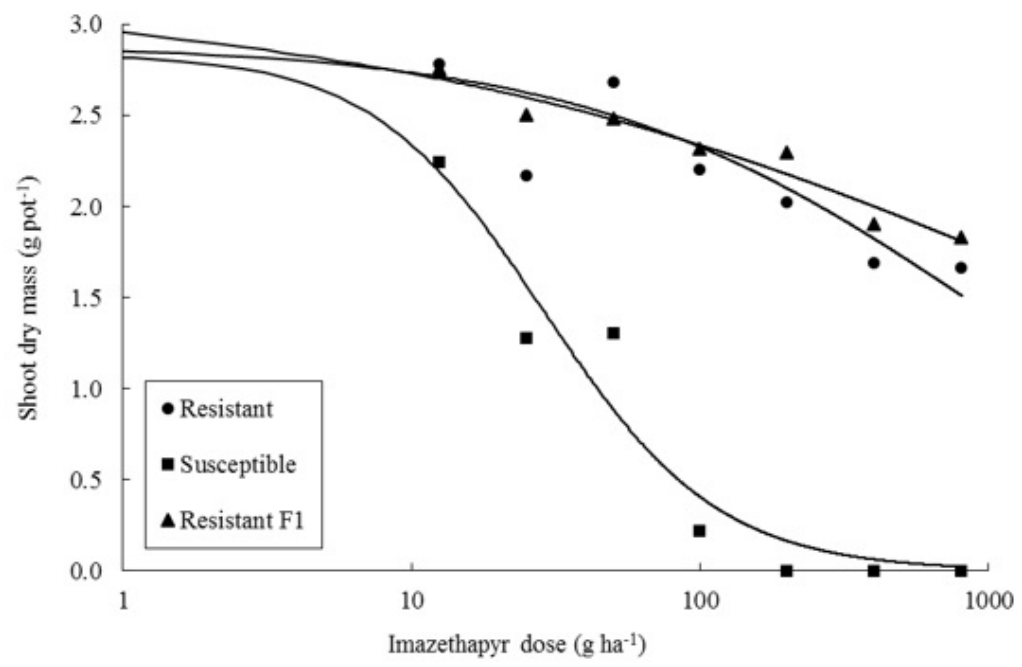

Figure 4: Response (g dry shoot biomass/pot) of Bidens pilosa populations to increasing doses of imazethapyr 28 days after application.

Considering that this is the first report of resistance to photosystem II inhibitors in BIDPI, the mechanisms that confer such resistance is still to be investigated. In other species, the resistance level to PSII inhibitors varies with resistance mechanism and species. It is common to find a point mutation in the gene encoding the D1 protein ( Ser $_{264}$ Gly), which causes a conformational change in the binding site for plastoquinone; other resistant species are able to metabolize the herbicide by glutathione conjugation or cytochrome P450 monooxygenase activity (Powles; Yu,
2010; Ma et al., 2013). Usually, mechanisms involving mutation of the binding site confer higher resistance level than the other mechanisms (Patzoldt; Tranel, 2007; Aspiazu et al., 2010; Huffman et al., 2015).

Research is necessary to understand the mechanisms of resistance in BIDPI, especially those related to the possibility of cross-resistance to other ALS and PSII inhibitors. The identification of resistance mechanisms could lead to the development of better management strategies for weed resistance. 


\section{CONCLUSIONS}

We confirmed the multiple resistance in the Bidens pilosa population from Quarto Centenário, Paraná, Brazil. This is the first case confirmed with multiple resistance to a Photosystem II inhibitor, atrazine, and an ALS inhibitor, imazethapyr, for this species.

\section{REFERENCES}

ASPIAZÚ, I. et al. Water use efficiency of cassava plants under competition conditions. Planta Daninha. 28(4):699-703, 2010.

BAIO, F. H. R.; PIRES, L. F.; TOMQUELSK, G. Mapeamento de picão-preto resistente aos herbicidas inibidores da ALS na região Sul Mato-Grossense. Bioscience Journal. 29(1):5964, 2013.

BRAZ, G. B. P. et al. Herbicidas alternativos no controle de Bidens pilosa e Euphorbia heterophylla resistentes a inibidores de ALS na cultura do algodão. Revista Brasileira de Herbicidas. 10(2):74-85, 2011.

BURGOS, N. R. et al. Confirmation of resistance to herbicides and evaluation of resistance levels. Weed Science. 61(1):420, 2013.

BURGOS, N. R. et al. Differential tolerance of weedy red rice (Oryza sativa L.) from Arkansas, USA to glyphosate. Crop Protection. 30(8):986-994, 2011.

CARVALHO, S. J. P. et al. Curvas de dose-resposta para avaliação do controle de fluxos de emergência de plantas daninhas pelo herbicida imazapic. Planta Daninha. 23(3):535-542, 2005.

CHRISTOFFOLETI, P. J. Curvas de dose-resposta de biótipos resistente e suscetível de Bidens pilosa L. aos herbicidas inibidores da ALS. Scientia Agricola. 59(3):513-519, 2002.

DAN, H. A. et al. Controle de plantas daninhas na cultura do milho por meio de herbicidas aplicados em pré-emergência. Pesquisa Agropecuária Tropical. 40(4):388-393, 2010.

FARIA, R. M.; BARROS, R. E.; TUFFI SANTOS, L. D. Weed interference on growth and yield of transgenic maize. Planta Daninha. 32(3):515-520, 2014.

FRANCISCHINI, A. C. et al. Resistance of Amaranthus retroflexus to acetolactate synthase inhibitor herbicides in Brazil. Planta Daninha. 32(2):437-446, 2014.

FREITAS, R. S. et al. Manejo de plantas daninhas na cultura do algodoeiro com S-metolachlor e trifloxysulfuron- sodium em sistema de plantio convencional. Planta Daninha. 24(2):311-318, 2006.

GROMBONE-GUARATINI, M. T.; SOLFERINI, V. N.; SEMIR, J. Reproductive biology in species of Bidens L. (Asteraceae). Scientia Agrícola. 61(2):185-189, 2004.

GUERRA, N. et al. Efeito da modalidade de aplicação sobre o controle de Bidens pilosa resistente a herbicidas inibidores da enzima ALS. Global Science and Technology. 4(1):6169, 2011.

HEAP, I. International survey of herbicide resistant weeds. Weed Science. 2016. Available in: < http://weedscience. org/>. Access in: May 10, 2016.

HUANG, Y. L.; KAO, W. Y. Different breeding systems of three varieties of Bidens pilosa in Taiwan. Weed Research. 54(2):162-168, 2014.

HUFFMAN, J. et al. Genetics and inheritance of nontarget-site resistances to atrazine and mesotrione in a waterhemp (Amaranthus tuberculatus) population from Illinois. Weed Science. 63(4):799-809, 2015.

LAMEGO, F. P. et al. Molecular basis of resistance to ALSinhibitor herbicides in greater beggarticks. Weed Science. 57(5):474-481, 2009.

LOPEZ-OVEJERO, R. F. et al. Resistance and differential susceptibility of Bidens pilosa and B. subalternans biotypes to ALS-inhibiting herbicides. Scientia Agricola. 63(2):139145, 2006.

MA, R. et al. Distinct detoxification mechanisms confer resistance to mesotrione and atrazine in a population of waterhemp. Plant Physiology. 163(1):363-377, 2013.

MONQUERO, P. A.; CHRISTOFFOLETI, P. J.; CARRER, H. Biology, management and biochemical/genetic characterization of weed biotypes resistant to acetolactate synthase inhibitor herbicides. Scientia Agricola. 60(3):495-503, 2003.

OLIVEIRA NETO, A. M. et al. Estratégias de manejo de inverno e verão visando ao controle de Conyza bonariensis e Bidens pilosa. Planta Daninha. 28(5):1107-1116, 2010.

PATZOLDT, W. L.; TRANEL, P. J. Multiple ALS mutations confer herbicide resistance in waterhemp (Amaranthus tuberculatus). Weed Science. 55(5):421-428, 2007.

POWLES, S. B.; YU, Q. Evolution in action: Plants resistant to herbicides. Annual Review of Plant Biology. 61(2):317347, 2010.

RODRIGUES, B. N.; ALMEIDA, F. S. Guia de herbicidas. Londrina: $2011.697 \mathrm{p}$. 
SANTOS, G. et al. Multiple resistance of Conyza sumatrensis to chlorimuron-ethyl and to glyphosate. Planta Daninha. 32(2):409-416, 2014.

SOCIEDADE BRASILEIRA DA CIÊNCIA DAS PLANTAS DANINHAS SBCPD. Procedimentos para instalação, avaliação e análise de experimentos com herbicidas. Londrina: SBCPD, 1995.42p.
STREIBIG, J. C. Herbicide bioassay. Weed Research. 28(6):479484, 1988.

VIDAL, R. A. et al. Relação entre distância geográfica e variabilidade genética de uma população de Bidens spp. com resistência aos herbicidas inibidores de ALS. Planta Daninha. 24(1):149-155, 2006. 